\title{
Antitumour activity of abiraterone and diethylstilboestrol when administered sequentially to men with castration-resistant prostate cancer
}

\author{
A Omlin ${ }^{1,4}$, C J Pezaro ${ }^{1,4}$, S Zaidi ${ }^{2}$, D Lorente ${ }^{1}$, D Mukherji ${ }^{1}$, D Bianchini ${ }^{1}$, R Ferraldeschi ${ }^{1}$, S Sandhu ${ }^{1}$, \\ D Dearnaley ${ }^{2}$, C Parker $^{2}$, N Van As ${ }^{3}$, J S de Bono ${ }^{1,5}$ and G Attard ${ }^{\star, 1,5}$
}

${ }^{1}$ Prostate Cancer Targeted Therapy Group and Drug Development Unit, The Royal Marsden NHS Foundation Trust and The Institute of Cancer Research, Downs Road, Sutton, Surrey, UK; ${ }^{2}$ Academic Urology Unit, The Royal Marsden NHS Foundation Trust, Downs Road, Sutton, Surrey, UK and ${ }^{3}$ Academic Urology Unit, The Royal Marsden NHS Foundation Trust, Fulham Road, Chelsea, UK

Background: Abiraterone is a standard treatment for men with castration-resistant prostate cancer (CRPC). We evaluated the antitumour activity of abiraterone following the synthetic oestrogen diethylstilboestrol (DES).

Methods: Castration-resistant prostate cancer patients treated with abiraterone were identified. Demographics, response variables and survival data were recorded.

Results: Two-hundred and seventy-four patients received abiraterone, 114 (41.6\%) after DES. Pre-chemotherapy abiraterone resulted in $\geqslant 50 \%$ PSA declines in 35/41 (85.4\%) DES-naïve and 20/27 (74.1\%) DES-treated patients. Post-docetaxel abiraterone resulted in $\geqslant 50 \%$ PSA declines in 40/113 (35.4\%) DES-naïve and 23/81 (28.4\%) DES-treated patients. Time to PSA progression was similar regardless of prior DES.

Conclusion: Abiraterone has important antitumour activity in men with CRPC even after DES exposure.

In 1941, oestrogen therapy became the first reported hormonal manipulation for men with advanced prostate cancer (Huggins and Hodges, 2002), but was superseded by surgical and medical castration (Scott and Benjamin, 1945; Parmar et al, 1985). Diethylstilboestrol (DES) is a synthetic non-steroidal oestrogen that has been widely used in men with castration-resistant prostate cancer (CRPC). Several mechanisms have been proposed to explain DES activity, including reduction of luteinizing hormone, testosterone and androgenic steroid levels (Bosset et al, 2012), inhibition of telomerase activity (Geier et al, 2010); direct binding of the androgen receptor (AR) (Wang et al, 2010) and suppression of $\beta$-tubulin isotypes (Montgomery et al, 2005). High-dose
(5 mg daily) DES was associated with cardiovascular toxicity (Malkowicz, 2001), but low-dose DES $1 \mathrm{mg}$ daily had a more acceptable therapeutic ratio, with reported activity including $\geqslant 50 \%$ PSA declines in $23-43 \%$ of patients (Smith et al, 1998; Manikandan et al, 2005; Clemons et al, 2011; Wilkins et al, 2012) and time to PSA progression of 4-4.6 months (Clemons et al, 2011; Wilkins et al, 2012). Combined with dexamethasone, DES treatment resulted in $\geqslant 50 \%$ PSA declines in $64-68 \%$ of patients in a small randomised study (Shamash et al, 2011), but venothromboembolic events occurred in $22 \%$ of patients in the combination arm. Diethylstilboestrol continues to be used in men with CRPC in several countries. Furthermore, a clinical trial

\footnotetext{
*Correspondence: Dr G Attard; E-mail: gerhardt.attard@icr.ac.uk

${ }^{4}$ These authors contributed equally as first authors.

${ }^{5}$ Co-senior authors.
} 
randomising patients between LHRH analogue treatment or transcutaneous oestrogen patches is currently in progress (PATCH trial, NCT00303784).

Abiraterone is an irreversible, selective, CYP17A1 inhibitor that blocks steroidal conversion to androgens and oestrogens. Large Phase III studies confirmed abiraterone as an effective treatment in CRPC (de Bono et al, 2011; Ryan et al, 2012). With six survivalprolonging treatments for CRPC, understanding the activity of treatments administered sequentially has become critically important for physicians. This is particularly relevant given the current financial pressures on healthcare budgets and the hypothesis that sequential therapies may impact the efficacy of later-line treatments acting on similar pathways of tumour growth. We therefore sought to evaluate the antitumour activity of abiraterone after DES therapy.

\section{PATIENTS AND METHODS}

This was a retrospective analysis of all patients treated with abiraterone at the Royal Marsden NHS Foundation Trust (RM) hospital in Chelsea, London and Sutton, Surrey, UK. Patients were identified from the pharmacy dispensing records and received abiraterone with concomitant prednisolone $10 \mathrm{mg}$ daily or dexamethasone $0.5 \mathrm{mg}$ daily in the settings of Phase I, II or III clinical trials reported previously (Attard et al, 2008; Carden et al, 2008; Attard et al, 2009; Reid et al, 2010; de Bono et al, 2011; Ryan et al, 2012) $(N=123)$ and expanded access programs or post approval $(N=151)$. All clinical trial patients underwent baseline and three-monthly imaging by computed tomography (CT) and bone scan. Patients treated outside of trials had CT and bone scan imaging at baseline and every 6 months as per local practice guidelines.

Demographic and treatment-related data were collected using the electronic hospital record. The objective of this analysis was to report the response rate and survival of patients treated with abiraterone, taking into account prior treatment with DES and docetaxel. This analysis was approved by the RM Clinical Audit Committee (SE143). Prostate-specific antigen and soft tissue responses were assessed using Prostate Cancer Working Group 2 criteria (Scher et al, 2008). Prostate-specific antigen progression was defined as a confirmed $\geqslant 25 \%$ rise from nadir in patients with

Table 1. Patient characteristics

\begin{tabular}{l|c} 
Median age at diagnosis (years) & $\begin{array}{c}\text { AA pre-docetaxel DES } \\
\text { pre-treated } \\
(\mathbf{N}=\mathbf{2 7})\end{array}$ \\
\hline Range & 63.2 \\
\hline Median Gleason score & $45.3-80.7$ \\
\hline Range & 8 \\
\hline Median time from diagnosis to CRPC (years) & $6-10$ \\
\hline Range & 3.3 \\
\hline
\end{tabular}

\begin{tabular}{l}
$\begin{array}{c}\text { AA pre-docetaxe } \\
\text { DES naïve } \\
(\mathbf{N}=\mathbf{4 1})\end{array}$ \\
64.1 \\
\hline $44.8-79.6$ \\
\hline 8 \\
\hline $6-10$ \\
\hline 3.6 \\
$0.6-16.2$
\end{tabular}

\section{AA post-docetaxel DES pre-treated} $(\mathbf{N}=87)$

63.1

$43.9-77.7$

\begin{tabular}{|c|c|c|c|c|}
\hline Antiandrogens & $24(89)$ & $40(98)$ & $83(95)$ & $116(97)$ \\
\hline Single-agent steroids & $5(19)$ & $13(32)$ & $12(14)$ & $53(45)$ \\
\hline DES administered with steroids, $N(\%)$ & $5(19)$ & NA & $21(24)$ & NA \\
\hline Docetaxel prior to DES, $N(\%)$ & NA & NA & $25(29)$ & NA \\
\hline ECOG performance status at $\mathrm{AA}, N(\%)$ & & & (NA: 3) & (NA: 3) \\
\hline 0 & $15(56)$ & $25(61)$ & $18(21)$ & $25(21)$ \\
\hline 1 & $12(44)$ & $16(39)$ & $52(60)$ & $74(62)$ \\
\hline 2 & & & $14(16)$ & $17(14)$ \\
\hline
\end{tabular}

\begin{tabular}{|c|c|c|c|c|}
\hline Antiandrogens & $24(89)$ & $40(98)$ & $83(95)$ & $116(97)$ \\
\hline Single-agent steroids & 5 (19) & $13(32)$ & $12(14)$ & $53(45)$ \\
\hline DES administered with steroids, $N(\%)$ & $5(19)$ & NA & $21(24)$ & NA \\
\hline Docetaxel prior to DES, $N(\%)$ & NA & NA & $25(29)$ & NA \\
\hline ECOG performance status at $\mathrm{AA}, N(\%)$ & & & (NA: 3) & (NA: 3) \\
\hline 0 & $15(56)$ & $25(61)$ & $18(21)$ & $25(21)$ \\
\hline 1 & $12(44)$ & $16(39)$ & $52(60)$ & $74(62)$ \\
\hline 2 & & & $14(16)$ & $17(14)$ \\
\hline
\end{tabular}

Metastases at AA, $\mathbf{N}(\%)$

\begin{tabular}{|c|c|c|c|c|}
\hline $\begin{array}{l}\text { Bone } \\
\text { Nodal } \\
\text { Visceral }\end{array}$ & $\begin{array}{c}22(81) \\
9(33) \\
5(19)\end{array}$ & $\begin{array}{c}33(80) \\
18(44) \\
2(5)\end{array}$ & $\begin{array}{l}81(93) \\
38(44) \\
13(15)\end{array}$ & $\begin{array}{c}107(90) \\
59(50) \\
20(17)\end{array}$ \\
\hline Median PSA at AA $\left(\mu \mathrm{gl}^{-1}\right)$ & 193 & 39.9 & 435 & 213 \\
\hline Range & $14.8-2642$ & $3.5-870$ & $10-8580$ & $2.3-10335$ \\
\hline Median haemoglobin at $\mathrm{AA}\left(\mathrm{gl}^{-1}\right)$ & 12.7 & 12.7 & 11.5 & 11.2 \\
\hline Range & $9.7-15.4$ & $10.0-15.1$ & $8.1-14.7$ & $8.0-16.5$ \\
\hline Median alkaline phosphatase at $\mathrm{AA}\left(\mathrm{UI}^{-1}\right)$ & 87 & 96 & 158 & 147 \\
\hline Range & $41-518$ & $43-642$ & $23-2044$ & $34-2163$ \\
\hline Median albumin at $\mathrm{AA}\left(\left.\mathrm{g}\right|^{-1}\right)$ & 36 & 37 & 34 & 35 \\
\hline Range & $27-42$ & $31-48$ & $23-41$ & $24-47$ \\
\hline Median lactate dehydrogenase at $\mathrm{AA}\left(\mathrm{UI}^{-1}\right)$ & 172 & 174 & 205 & 217 \\
\hline Range & $78-576$ & $110-298$ & $72-2490$ & $119-1659$ \\
\hline
\end{tabular}


$a \geqslant 50 \%$ PSA decline and as a confirmed $\geqslant 25 \%$ rise from baseline in the remaining patients, disregarding progression prior to 12 weeks of therapy. Due to the impact of patient censoring, time to
PSA progression in the post-docetaxel groups was calculated using bootstrap analysis. Radiographic responses and progression were assessed using RECIST 1.1 in patients with measurable soft tissue

Table 2. Activity of abiraterone grouped by DES exposure

\begin{tabular}{|c|c|c|}
\hline AA pre-docetaxel & DES pre-treated $(\mathbf{N}=\mathbf{2 7})$ & DES naïve $(N=41)$ \\
\hline $\begin{array}{l}\text { Median duration of AA treatment (months, m) } \\
95 \% \mathrm{Cl}\end{array}$ & $\begin{array}{c}11.4 \\
7.6-16.8\end{array}$ & $\begin{array}{c}16.6 \\
12-21.7\end{array}$ \\
\hline \multirow[t]{2}{*}{$\begin{array}{l}\text { Median duration of DES treatment }(\mathrm{m}) \\
95 \% \mathrm{Cl}\end{array}$} & $\begin{array}{l}11.4 \\
8-15\end{array}$ & \\
\hline & $\mathbf{N}(\%)$ & $\mathbf{N}(\%)$ \\
\hline$\geqslant 50 \%$ PSA decline & $20(74.1)$ & $35(85.4)$ \\
\hline$\geqslant 30 \%$ PSA decline & $22(81.5)$ & $37(90.2)$ \\
\hline Soft tissue response & $4 / 10(40)$ & $9 / 18(50)$ \\
\hline $\begin{array}{l}\text { Median survival from start of AA }(m) \\
95 \% \mathrm{Cl}\end{array}$ & $\begin{array}{c}36.7 \\
11.1-62.4\end{array}$ & $\begin{array}{c}40.5 \\
27.8-53.2\end{array}$ \\
\hline $\begin{array}{l}\text { Median time to PSA progression on AA }(\mathrm{m}) \\
95 \% \mathrm{Cl} \\
\text { Number of evaluable patients }\end{array}$ & $\begin{array}{c}8.5 \\
3.0-14.1 \\
24\end{array}$ & $\begin{array}{c}9.2 \\
5.7-12.7 \\
39\end{array}$ \\
\hline $\begin{array}{l}\text { Median time to radiographic soft tissue progression on AA }(\mathrm{m}) \\
95 \% \mathrm{Cl} \\
\text { Number of evaluable patients }\end{array}$ & $\begin{array}{c}11.9 \\
0-30.6 \\
10\end{array}$ & $\begin{array}{c}13.8 \\
8.3-19.3 \\
18\end{array}$ \\
\hline Abiraterone (AA) post-docetaxel & DES pre-treated $(\mathbf{N}=\mathbf{8 7})$ & DES naïve $(N=119)$ \\
\hline $\begin{array}{l}\text { Median duration of } \mathrm{AA} \text { treatment }(\mathrm{m}) \\
95 \% \mathrm{Cl}\end{array}$ & $\begin{array}{c}5.5 \\
4.4-6.5\end{array}$ & $\begin{array}{c}4.3 \\
3.7-5.6\end{array}$ \\
\hline \multirow[t]{2}{*}{$\begin{array}{l}\text { Median duration of DES treatment }(\mathrm{m}) \\
95 \% \mathrm{Cl}\end{array}$} & $\begin{array}{c}9 \\
5.8-15\end{array}$ & \\
\hline & $\mathbf{N}(\%)$ & $\mathbf{N}(\%)$ \\
\hline$\geqslant 50 \%$ PSA decline & $23 / 81(28.4)$ & 40/113 (35.4) \\
\hline$\geqslant 30 \%$ PSA decline & $34 / 81(42)$ & $55 / 113(48.7)$ \\
\hline Soft tissue response & 9/36 (25) & $6 / 40(15)$ \\
\hline $\begin{array}{l}\text { Median survival from start of AA }(\mathrm{m}) \\
95 \% \mathrm{Cl}\end{array}$ & $\begin{array}{c}13.4 \\
9.8-17\end{array}$ & $\begin{array}{c}13.4 \\
9.8-16.7\end{array}$ \\
\hline $\begin{array}{l}\text { Median time to PSA progression on AA }(\mathrm{m}) \\
95 \% \mathrm{Cl} \\
\text { Number of evaluable patients }\end{array}$ & $\begin{array}{c}4.3 \\
3.5-5.5 \\
71\end{array}$ & $\begin{array}{c}4.3 \\
3.7-5.5 \\
91\end{array}$ \\
\hline $\begin{array}{l}\text { Median time to radiographic soft tissue progression on } \mathrm{AA}(\mathrm{m}) \\
95 \% \mathrm{Cl} \\
\text { Number of evaluable patients }\end{array}$ & $\begin{array}{c}2.9 \\
1.6-4.2 \\
36\end{array}$ & $\begin{array}{c}2.7 \\
2.5-2.9 \\
40\end{array}$ \\
\hline
\end{tabular}

DES post abiraterone, $\mathbf{N}=\mathbf{3 1}$

Performance status at start of DES, $\mathbf{N}(\%)$

\begin{tabular}{|c|c|c|}
\hline 0 & \multicolumn{2}{|c|}{$4(13)$} \\
\hline 1 & \multicolumn{2}{|c|}{$10(32)$} \\
\hline 2 & \multicolumn{2}{|c|}{$13(42)$} \\
\hline 3 & \multicolumn{2}{|c|}{$4(13)$} \\
\hline Median PSA at start of DES $\left(\mu \mathrm{gl}^{-1}\right)$ & \multicolumn{2}{|c|}{399} \\
\hline Range & \multicolumn{2}{|c|}{$13.8-22^{\prime} 299$} \\
\hline & DES (PSA evaluable $\boldsymbol{N}=23$ ) & Prior abiraterone \\
\hline Median time on treatment $(\mathrm{m})$ & 2.7 & 11.2 \\
\hline $95 \% \mathrm{Cl}$ & $1.8-4.4$ & \\
\hline Range & $0.1-31.2$ & $0.9-32.7$ \\
\hline$\geqslant 50 \%$ PSA decline, $N(\%)$ & $2 / 23(9)$ & $17 / 31(55)$ \\
\hline Median survival from start of DES (m) & \multicolumn{2}{|c|}{4.8} \\
\hline Range & \multicolumn{2}{|c|}{$0.2-46.4$} \\
\hline
\end{tabular}


disease (Eisenhauer et al, 2009). Date cut-off for follow-up was 31 December 2012 and patients still alive or lost to follow-up were censored.

Descriptive statistics and Kaplan-Meier survival analyses were performed using IBM SPSS Statistics v20 (IBM).

\section{RESULTS}

Patient characteristics. Between January 2006 and October 2012, a total of 274 patients received abiraterone. The patient population is described in Table 1. Of these, 114 were treated with DES prior to abiraterone at doses of 1 to $3 \mathrm{mg}$ per day with or without aspirin and/or dexamethasone as per institutional standards. The majority of patients (106, 96.3\%, 4 patients not known) received at least 30 days of DES. Diethylstilboestrol was discontinued in 86 (75.4\%) men due to progressive disease, whereas 18 (15.8\%) discontinued due to toxicity (reason unknown in 10 patients). A total of 68 patients were treated with abiraterone prior to chemotherapy, whereas 206 patients were treated with abiraterone after docetaxel (see Table 2). The median follow-up for the overall cohort was 58 months. The antitumour activity of abiraterone is lower in docetaxel-treated compared with docetaxel-naïve patients (Attard et al, 2009; Reid et al, 2010; Ryan et al, 2010; de Bono et al, 2011; Ryan et al, 2013), and we have therefore reported the activity of abiraterone post-DES in these two settings separately. Of the 68 docetaxel-naïve patients treated with abiraterone, 27 had previously received DES. Of the 206 docetaxel-treated patients who received abiraterone, 87 had been treated with DES.

Abiraterone administered prior to docetaxel. Activity measures for the 27 men treated with abiraterone following DES are shown in Table 2 and Figure 1, including $\geqslant 50 \%$ PSA declines in 20 patients $(74.1 \%)$, a median time to PSA progression of 8.5 months and median duration of treatment of 11.4 months. Median survival from start of abiraterone was 36.7 months (95\% CI 11.1-62.4). In comparison, $\geqslant 50 \%$ PSA declines occurred in 35 of the 41 patients (85.4\%) who received abiraterone without prior DES exposure, with median time to PSA progression of 9.2 months and median treatment duration of 16.6 months. In these patients, the
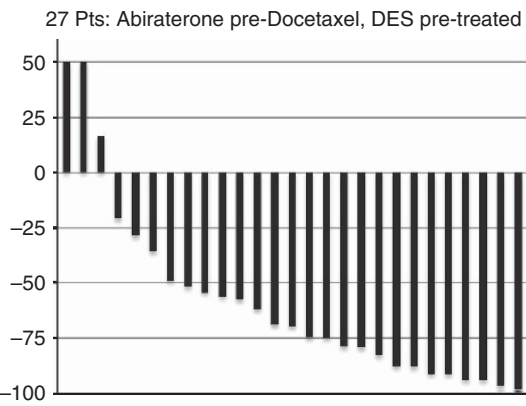

81 Pts: Abiraterone post Docetaxel, DES pre-treated

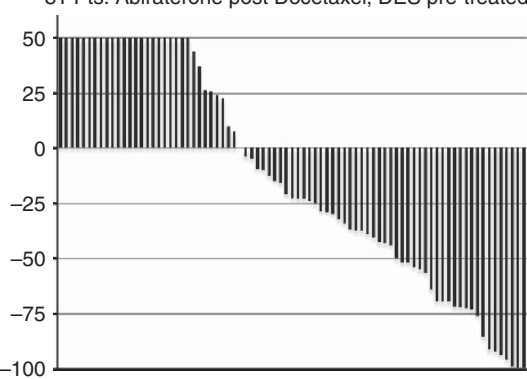

median survival from start of abiraterone was 40.5 months ( $95 \%$ CI 27.8-53.2).

Abiraterone administered after docetaxel. A total of 87 men were treated with abiraterone after DES and docetaxel. Maximum PSA declines of $\geqslant 50 \%$ occurred in 23 of the 81 evaluable patients (28.4\%) and median time to PSA progression was 4.3 months (16 patients discontinued therapy prior to 12 weeks and were not included in progression analysis). Patients remained on treatment with abiraterone for a median of 5.5 months. Median survival was 13.4 months (95\% CI 9.8-17.0). A total of 119 patients received abiraterone after docetaxel with no prior DES exposure. Declines of PSA $\geqslant 50 \%$ occurred in 40 of 113 patients evaluable for PSA response $(35.4 \%)$ with a median time to PSA progression of 4.3 months (28 patients discontinued therapy prior to 12 weeks). Patients received abiraterone for a median of 4.3 months and the median survival was 13.4 months (95\% CI 9.8-16.7).

Diethylstilboestrol administered after abiraterone. A total of 31 patients received DES after abiraterone. In this cohort, 28 (90.3\%) patients had also received docetaxel and one patient had been treated with cabazitaxel chemotherapy. The median duration of abiraterone prior to DES was 11.2 months (see Table 2). The median duration of DES treatment was 2.7 months (range $0.1-31.2)$. Diethylstilboestrol was discontinued due to progression in $18(62 \%)$ and toxicity in four (13.8\%) patients (reason unknown in five patients and patient death in three patients). Prostatespecific antigen declines of $\geqslant 50 \%$ occurred in $8.7 \%(2 / 23)$ evaluable patients. No objective soft tissue responses were seen in the six evaluable patients. The majority of patients did not have follow-up scans due to declining performance status.

Of 14 patients who received DES for $>3$ months, four were docetaxel-naïve at start of DES treatment (three of these patients, however, received docetaxel after DES) and seven (50\%) had $\geqslant 90 \%$ PSA declines on abiraterone.

Another patient discontinued abiraterone after 27 days of treatment due to an acute pulmonary embolism; abiraterone was not re-started because it was impossible to exclude a causal relationship. This patient had a subsequent $80 \%$ PSA decline on DES and remained on treatment for 31.3 months.

41 Pts: Abiraterone pre-Docetaxel, no prior DES
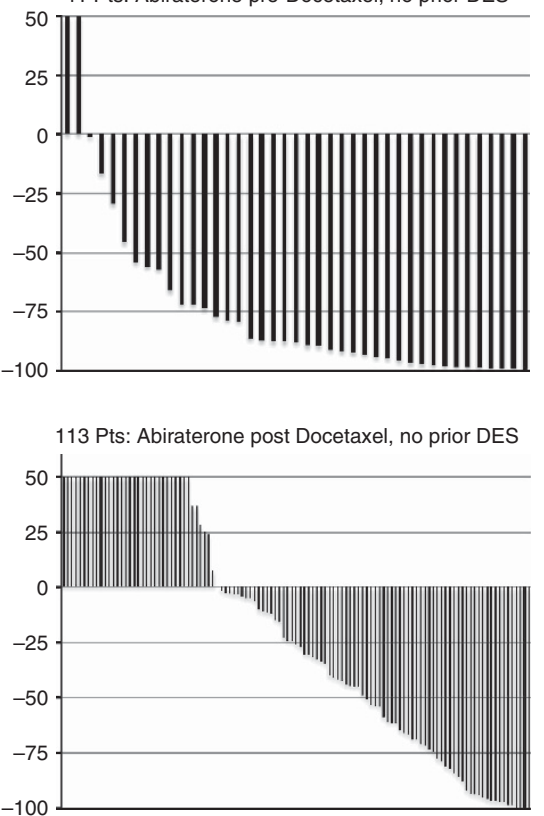

Figure 1. Waterfall plots of maximum PSA decline on abiraterone. PSA increases of $>50 \%$ were capped. Abbreviation: Pts $=$ patients. 


\section{DISCUSSION}

In this large, single-centre cohort of CRPC patients, abiraterone retained significant and clinically important activity after DES treatment. Prior DES exposure appeared to have minimal impact on overall abiraterone activity. We also report the activity of DES after abiraterone, which was prospectively collected for our patients. In these patients, DES was primarily used in the end-stage setting when no other treatment was possible due to availability or patient fitness and its activity in this setting was very modest. Patients who received $>3$ months DES treatment were mainly patients who had substantial PSA declines and long durations of treatment on abiraterone or those who stopped abiraterone prematurely. The short treatment duration and survival on DES after abiraterone and docetaxel reflect the advanced state of these patients and may therefore have underestimated the activity of DES post abiraterone. Recent reports suggest both abiraterone and enzalutamide have lower activity in patients with poorer performance status (de Bono et al, 2011; Scher et al, 2012; Loriot et al, 2013; Noonan et al, 2013). We did not have robust data available to evaluate the activity of DES treatment prior to abiraterone.

These data are retrospective in nature. The sample size of the cohorts, especially in chemotherapy-naïve patients, is limited. Furthermore, we assessed abiraterone activity using PSA endpoints, which are commonly used activity endpoints, but not robust surrogates of overall survival(Fleming et al, 2006). Of note, the median time on DES in our pre-chemotherapy cohort was considerably longer than previously reported (Wilkins et al, 2012). It is likely that patients with a good response to prior hormonal manipulations and no clinical indication for cytotoxic chemotherapy were positively selected in the Phase II trials of abiraterone pre-chemotherapy.

The landscape of treatments for CRPC is changing rapidly and abiraterone was recently approved in the pre-chemotherapy setting. This analysis demonstrates that abiraterone remains an active treatment in patients after prior DES treatment. Given the efficacy of abiraterone and the toxicity of DES, abiraterone will increasingly be used prior to DES, although financial constraints may limit the use of abiraterone in certain settings. The antitumour activity of DES after abiraterone in this cohort of patients was limited, indicating that other treatment options or clinical trials should be considered in fit abiraterone-resistant patients. Similarly, our data suggest very limited activity with DES in poor performance, end-stage patients who previously received abiraterone.

\section{ACKNOWLEDGEMENTS}

The authors are employees of the Section of Medicine that is supported by a Cancer Research UK programme grant and an Experimental Cancer Medical Centre (ECMC) grant from Cancer Research UK and the Department of Health (Ref: C51/A7401). GA is supported by a Cancer Research UK Clinician Scientist Fellowship. The authors acknowledge NHS funding to the Royal Marsden NIHR Biomedical Research Centre. AO is recipient of a 2-year bursary from the Swiss Cancer League (No. BIL KLS-0259202-2010).

\section{CONFLICT OF INTEREST}

Abiraterone acetate was developed at The Institute of Cancer Research, which therefore has a commercial interest in the development of this agent. CP received lecture fees from Sanofi-
Aventis and travel support from Sanofi-Aventis and Janssen-Cilag. DD received honoraria for advisory boards and served as a consultant for Takeda, Amgen, Astellas Pharma and Succinct Healthcare. JSdB received consulting fees from Ortho Biotech Oncology Research and Development (a unit of Cougar Biotechnology), consulting fees and travel support from Amgen, Astellas, AstraZeneca, Boehringer Ingelheim, Bristol-Myers Squibb, Dendreon, Enzon, Exelixis, Genentech, GlaxoSmithKline, Medivation, Merck, Novartis, Pfizer, Roche, Sanofi-Aventis, Supergen and Takeda, and grant support from AstraZeneca and Genentech. GA received consulting fees and travel support from Janssen-Cilag, Veridex, Roche/Ventana and Millennium Pharmaceuticals, lecture fees from Janssen-Cilag, Ipsen, Takeda and Sanofi-Aventis and grant support from AstraZeneca and Genentech. GA and DD are on The ICR rewards to inventors list of abiraterone acetate.

\section{REFERENCES}

Attard G, Reid AH, A'Hern R, Parker C, Oommen NB, Folkerd E, Messiou C, Molife LR, Maier G, Thompson E, Olmos D, Sinha R, Lee G, Dowsett M, Kaye SB, Dearnaley D, Kheoh T, Molina A, de Bono JS (2009) Selective inhibition of CYP17 with abiraterone acetate is highly active in the treatment of castration-resistant prostate cancer. J Clin Oncol 27(23): 3742-3748.

Attard G, Reid AH, Yap TA, Raynaud F, Dowsett M, Settatree S, Barrett M, Parker C, Martins V, Folkerd E, Clark J, Cooper CS, Kaye SB, Dearnaley D, Lee G, de Bono JS (2008) Phase I clinical trial of a selective inhibitor of CYP17, abiraterone acetate, confirms that castration-resistant prostate cancer commonly remains hormone driven. J Clin Oncol 26(28): 4563-4571.

Bosset PO, Albiges L, Seisen T, de la Motte Rouge T, Phe V, Bitker MO, Roupret M (2012) Current role of diethylstilbestrol in the management of advanced prostate cancer. BJU Int 110: E826-E829.

Carden CP, Raynaud FI, Jones RL, Riggs SB, Martins V, Oommen N, McIntosh D, Lee G, De Bono JS, Kabbinavar FF (2008) Crossover pharmacokinetics (PK) study to assess oral administration of abiraterone acetate capsule and tablet formulations in fasted and fed states in patients with prostate cancer. J Clin Oncol 26(suppl): abstract 5168.

Clemons J, Glode LM, Gao D, Flaig TW (2011) Low-dose diethylstilbestrol for the treatment of advanced prostate cancer. Urol Oncol 31: 198-204.

de Bono JS, Logothetis CJ, Molina A, Fizazi K, North S, Chu L, Chi KN, Jones RJ, Goodman Jr. OB, Saad F, Staffurth JN, Mainwaring P, Harland S, Flaig TW, Hutson TE, Cheng T, Patterson H, Hainsworth JD, Ryan CJ, Sternberg CN, Ellard SL, Flechon A, Saleh M, Scholz M, Efstathiou E, Zivi A, Bianchini D, Loriot Y, Chieffo N, Kheoh T, Haqq CM, Scher HI (2011) Abiraterone and increased survival in metastatic prostate cancer. New Engl J Med 364(21): 1995-2005.

Eisenhauer EA, Therasse P, Bogaerts J, Schwartz LH, Sargent D, Ford R, Dancey J, Arbuck S, Gwyther S, Mooney M, Rubinstein L, Shankar L, Dodd L, Kaplan R, Lacombe D, Verweij J (2009) New response evaluation criteria in solid tumours: revised RECIST guideline (version 1.1). Eur J Cancer 45(2): 228-247.

Fleming MT, Morris MJ, Heller G, Scher HI (2006) Post-therapy changes in PSA as an outcome measure in prostate cancer clinical trials. Nat Clin Pract Oncol 3(12): 658-667.

Geier R, Adler S, Rashid G, Klein A (2010) The synthetic estrogen diethylstilbestrol (DES) inhibits the telomerase activity and gene expression of prostate cancer cells. Prostate 70(12): 1307-1312.

Huggins C, Hodges CV (2002) Studies on prostatic cancer: I. The effect of castration, of estrogen and of androgen injection on serum phosphatases in metastatic carcinoma of the prostate. 1941. J Urol 168(1): 9-12.

Loriot Y, Bianchini D, Ileana E, Sandhu S, Patrikidou A, Pezaro C, Albiges L, Attard G, Fizazi K, De Bono JS, Massard C (2013) Antitumour activity of abiraterone acetate against metastatic castration-resistant prostate cancer progressing after docetaxel and enzalutamide (MDV3100). Ann Oncol 24(7): 1807-1812.

Malkowicz SB (2001) The role of diethylstilbestrol in the treatment of prostate cancer. Urology 58(2 Suppl 1): 108-113.

Manikandan R, Srirangam SJ, Pearson E, Brown SC, O’Reilly P, Collins GN (2005) Diethylstilboestrol versus bicalutamide in hormone refractory prostate carcinoma: a prospective randomized trial. Urol Int 75(3): 217-221. 
Montgomery RB, Bonham M, Nelson PS, Grim J, Makary E, Vessella R, Stahl WL (2005) Estrogen effects on tubulin expression and taxane mediated cytotoxicity in prostate cancer cells. The Prostate 65(2): 141-150.

Noonan KL, North S, Bitting RL, Armstrong AJ, Ellard SL, Chi KN (2013) Clinical activity of abiraterone acetate in patients with metastatic castration-resistant prostate cancer progressing after enzalutamide. Ann Oncol 24(7): 1802-1807.

Parmar H, Phillips RH, Lightman SL, Edwards L, Allen L, Schally AV (1985) Randomised controlled study of orchidectomy vs long-acting D-Trp-6LHRH microcapsules in advanced prostatic carcinoma. Lancet 2(8466): 1201-1205.

Reid AH, Attard G, Danila DC, Oommen NB, Olmos D, Fong PC, Molife LR, Hunt J, Messiou C, Parker C, Dearnaley D, Swennenhuis JF, Terstappen LW, Lee G, Kheoh T, Molina A, Ryan CJ, Small E, Scher HI, de Bono JS (2010) Significant and sustained antitumor activity in post-docetaxel, castration-resistant prostate cancer with the CYP17 inhibitor abiraterone acetate. J Clin Oncol 28(9): 1489-1495.

Ryan CJ, Smith MR, de Bono JS, Molina A, Logothetis CJ, de Souza P, Fizazi K, Mainwaring P, Piulats JM, Ng S, Carles J, Mulders PF, Basch E, Small EJ, Saad F, Schrijvers D, Van Poppel H, Mukherjee SD, Suttmann H, Gerritsen WR, Flaig TW, George DJ, Yu EY, Efstathiou E, Pantuck A, Winquist E, Higano CS, Taplin ME, Park Y, Kheoh T, Griffin T, Scher HI, Rathkopf DE (2012) Abiraterone in metastatic prostate cancer without previous chemotherapy. New Engl J Med 368: 138-148.

Ryan CJ, Smith MR, Fong L, Rosenberg JE, Kantoff P, Raynaud F, Martins V, Lee G, Kheoh T, Kim J, Molina A, Small EJ (2010) Phase I clinical trial of the CYP17 inhibitor abiraterone acetate demonstrating clinical activity in patients with castration-resistant prostate cancer who received prior ketoconazole therapy. J Clin Oncol 28(9): 1481-1488.
Scher HI, Fizazi K, Saad F, Taplin ME, Sternberg CN, Miller K, de Wit R, Mulders P, Chi KN, Shore ND, Armstrong AJ, Flaig TW, Flechon A, Mainwaring P, Fleming M, Hainsworth JD, Hirmand M, Selby B, Seely L, de Bono JS (2012) Increased survival with enzalutamide in prostate cancer after chemotherapy. New Engl J Med 367(13): 1187-1197.

Scher HI, Halabi S, Tannock I, Morris M, Sternberg CN, Carducci MA, Eisenberger MA, Higano C, Bubley GJ, Dreicer R, Petrylak D, Kantoff P, Basch E, Kelly WK, Figg WD, Small EJ, Beer TM, Wilding G, Martin A, Hussain M (2008) Design and end points of clinical trials for patients with progressive prostate cancer and castrate levels of testosterone: recommendations of the Prostate Cancer Clinical Trials Working Group. J Clin Oncol 26(7): 1148-1159.

Scott WW, Benjamin JA (1945) The role of bilateral orchiectomy in the treatment of carcinoma of the prostate gland. Bull N Y Acad Med 21(6): 307-332.

Shamash J, Powles T, Sarker SJ, Protheroe A, Mithal N, Mills R, Beard R, Wilson P, Tranter N, O’Brien N, McFaul S, Oliver T (2011) A multi-centre randomised phase III trial of Dexamethasone vs Dexamethasone and diethylstilbestrol in castration-resistant prostate cancer: immediate vs deferred Diethylstilbestrol. Br J Cancer 104(4): 620-628.

Smith DC, Redman BG, Flaherty LE, Li L, Strawderman M, Pienta KJ (1998) A phase II trial of oral diethylstilbesterol as a second-line hormonal agent in advanced prostate cancer. Urology 52(2): 257-260.

Wang H, Li J, Gao Y, Xu Y, Pan Y, Tsuji I, Sun ZJ, Li XM (2010) Xeno-oestrogens and phyto-oestrogens are alternative ligands for the androgen receptor. Asian J Androl 12(4): 535-547.

Wilkins A, Shahidi M, Parker C, Gunapala R, Thomas K, Huddart R, Horwich A, Dearnaley D (2012) Diethylstilbestrol in castration-resistant prostate cancer. BJU Int 110: E727-E735. 